\title{
Ervin Sinkó's Search for Community: The Early Years, 1898-1919
}

\section{George Deák}

\begin{abstract}
Before the political shift that occurred in1989, the biographies of early communists who had participated in the Hungarian Soviet Republic of 1919 could not be the subjects of critical histories. Later, such historical actors were either vilified or simply neglected. This article contributes to the reversal of this neglect by examining the youth of the novelist Ervin Sinkó (1898-1967), who both participated in the rule of the Soviet Republic and authored Optimisták, Történelmi regény 1918-1919-böl ['The Optimists, a Historical Novel About 1918-1919']. The experience of anti-Semitism and traumas caused by the First World War led Sinkó through a number of fluid, intermediary stages that culminated in his support of communism; eventually, however, Sinkó's experiences within the Soviet Republic's regime prompted him to abandon communism in favor of an idiosyncratic form of Christianity. From another perspective, this work also traces the concurrent development of Sinkó's personality, from that of an aggressive adolescent to a compassionate adult.
\end{abstract}

Keywords: Communism, anti-Semitism, Ervin Sinkó, Irma Rothbart, Hungarian Soviet Republic, Jewish conversion, pacifism

Biography: A retired software engineer, George Deák is also an independent historian and translator. He has taught at the University of Massachusetts, Lowell, and is currently an Associate of the Davis Center for Russian and Eurasian Studies at Harvard University. Published in 2018, his abridgement and translation of Ervin Sinkó's The Novel of a Novel has been reviewed in this issue of HCS. He received his PhD from Columbia University in 1980 and has also written about the early history of GyOSz, the National Association of Hungarian Industrialists (19021914).deakgy62@gmail.com

The Hungarian writer Ervin Sinkó (1898-1967) is best known for two works. His most important novel, Optimisták, Történelmi regény 1918-1919-böl ['Optimists, A Historical Novel about 1918-1919'], written between 1931 and 1934, describes a seminal episode in the history of Hungarian communism. His signature non-fictional work, Egy regény regénye ['The Novel of a Novel'], written in 1953, is a memoir based on his personal diaries and describes his attempts to publish Optimists during the Great Terror in the Soviet Union between 1935 and 1937. Sinkó's life, like his major works, reflect the dilemmas faced by many well-intentioned people in the "short twentieth century" who found the experience of communism to be quite different from their expectations of it, yet - even after repeated disappointments - remained with or returned to the movement. This paper explores how a biography of Sinkó may help later generations understand why someone like Sinkó, a Hungarian intellectual of Jewish ancestry, could be both 
Deák, George. "Ervin Sinkó's Search for Community: The Early Years, 1898-1919.” Hungarian Cultural Studies. e-Journal of the American Hungarian Educators Association, Volume 12 (2019) DOI: 10.5195/ahea.2019.348

attracted to and repulsed by communism. In this biographical essay I will concentrate on Sinkó's youth and examine the development of two largely parallel processes, one related to personality, the other to concepts concerning society, politics and ethics. I will therefore examine the question of how a rather self-centered, at times aggressive adolescent growing up during the early years of World War I could mature into a considerate, empathetic adult while (over the course of the same years, from 1916 to1919) adopting communism and then rejecting it in favor of a pacifism modeled on his understanding of the teachings of Jesus.

Although the recent Hungarian-language republications of his two major works and the convocation of a conference on Sinkó in Budapest in April 2014 demonstrate that interest in his literary output, ideas and life story continues to exist, a full biography of Ervin Sinkó is yet to be written. A great deal of preliminary spadework for a biography was completed by István Baranyai-Bosnyák (1940-2009), one of Sinkó's students at the Department of Hungarian Language and Literature at the University of Novi Sad. Yet, Bosnyák failed, perhaps for political reasons, to produce a Sinkó biography (Sinkó 1990; Bosnyák 1977). It is high time for a Sinkó biography free of both communist and anti-communist blinders to be brought to the public.

Aspects of Sinkó's life throughout the period under examination can be reconstructed from several sources. Sinkó kept revealing diaries in 1916 and early 1917 (Sinkó 1990: 25-63). Already in 1920, Sinkó also wrote a non-fictional account entitled $A z$ Út ['The Way'] relaying his activities in the Soviet Republic and his conversion to a non-denominational form of Christianity (Sinkó 1990: 64-152). In 1935, Sinkó composed a short autobiography for the French communist-oriented journal Monde entitled En face du juge, ['Szemben a bíróval,' 'Facing the Judge'] (Sinkó 1977). Additional testimony describing Sinkó's actions during the Soviet Republic may be gathered from József Lengyel, another writer from the same revolutionary generation as Sinkó who described his own activities and perspectives on the Soviet Republic in the memoir Visegrádi utca ['Visegrád Street'] (Lengyel 1968), that was written in 1928. Research based on newspapers and other contemporary documents by Bosnyák and Ignác Romsics corroborate the basic outlines of Sinkó's activities during the Hungarian Commune (Sinkó 1990: 414-44; Romsics 1982: 103-106, 114-15). In addition, we have Sinkó's highly autobiographical novel, Optimists, written between 1931-1934. Although some simplifying discrepancies can be found when comparing Sinkó's life to the story of the novel's protagonist, József Báti, both Sinkó's teenage diaries and his work, The Way, make it clear that many of the episodes in the novel bear a close correlation to reality.

Since Optimists is not only central to our understanding of Sinkó's life but was written largely to explain the transformational processes that are the focus of this essay, it is worthwhile to describe the work at the outset. As regards genre, Optimists is a roman à clef about the Hungarian Soviet Republic. Other than Sinkó, represented via the character Báti, some of the characters include (with their fictional names in parentheses, according to information that was kindly supplied to me by Tatiana Lengyel) the Marxist philosopher György Lukács (Vértes), the agit-prop poet Aladár Komját (Lénárt), the journalist József Lengyel (Sarkadi), a founding member of the Party of Communists in Hungary (KMP) and the later minister of the Hungarian Soviet Republic Ottó Korvin (Kovács), the engineer and communist functionary Gyula Hevesi (Stein), the leader of the self-styled "Terrorists" or "Lenin Boys," József Cserny (Dani), and Báti's love, Irma Rothbart (Erzsi Cinner), later Sinkó's wife. 
Deák, George. "Ervin Sinkó's Search for Community: The Early Years, 1898-1919.” Hungarian Cultural Studies. e-Journal of the American Hungarian Educators Association, Volume 12 (2019) DOI: 10.5195/ahea.2019.348

The novel centers on Báti, a restless adolescent from a middle-class Jewish family living in the sleepy southern Hungarian town of Szabadka (now Serbia, Subotica), who drops out of gimnázium [a type of rigorous secondary school] to pursue his passion first for Social Democracy, and then, after the outbreak of war in 1914, for Nietzsche and poetry. Mainly occupied with spending his nights at the artists' table in the town's central café while World War I rages, Báti is taken to the Galician front as he reaches draft age. He experiences first-hand the horrors of war and returns to Szabadka not long before the dissolution of the Monarchy at the end of October 1918. With hardly a penny in his pocket, Báti leaves for Budapest, hoping to take part in the revolution that he is certain will erupt as armed, disgruntled troops stream back to the defeated country. In Budapest, he encounters a group of young people in a café who, dissatisfied with the gradualism of the Károlyi government's bourgeois republic, are indeed agitating for a Marxist revolution. Erzsi is a member of this group and Báti falls in love with her weeks before they exchange a word. However, she is already in a relationship with the married but insatiable Lénárt, who is also intimate with two of Erzsi's former roommates from boarding school, one of whom is his wife. Much of the novel is about how Báti woos the unwilling Erzsi while they try to convince the Hungarian working-class to join the revolution that the group expects to sweep through Europe imminently. Báti becomes a founding member of a journal, International.

Yet the central drama in the novel is Báti's struggle with the ideology of communism. Soon after the Béla Kun-led Hungarian Soviet Republic is established on March 21, 1919, Báti is given an official role as an agitator and then sent to the countryside as a recruiter for the Red Army. Within a matter of weeks, he becomes the city commissar of Kecskemét, where a rightist plot threatened to overthrow Soviet rule in the town. Báti must suppress the rebellion but recoils from the random brutality of the very defenders whom he has called upon to help. The question of the justifiability and necessity of revolutionary violence therefore shapes one of the novel's main themes. Báti shifts from being a supporter of the brilliant Vértes (Lukács), who provides a theoretical justification for revolutionary violence, to conversion to a Christian creed that declares all violence as immoral. Even though Báti takes up arms to defend the revolution in Budapest against its domestic attackers, he announces toward the end of the novel to Erzsi that he is no longer a communist.

\section{Sinkó's background and early attraction to Social Democracy}

Originally born as Ferenc Spitzer in 1898, Ervin Sinkó spent his early childhood in the village of Apatin, in what was then Southern Hungary [Délvidék] and is today within Serbia. At the time, the major city in this region was Szabadka [today: Subotica]. Sinkó's father was a prosperous, assimilated Jewish merchant who sold and exported articles made of jute or hemp, commodities that were essential for the swiftly growing agricultural economy of the region. Sinkó and his three siblings grew up in a comfortable, close-knit, supportive home, but in isolation from their neighbors, who were mostly Christian in faith and sváb [Swabian, a German ethnic group] in ethnicity.

Sinkó tells us in Facing the Judge that the encounter with anti-Semitism was his initial experience with injustice, an experience that later propelled him towards socialism. As a child, Sinkó had wanted to join the village boys in play, but was not accepted. The most traumatic incident was when he was dragged into a ditch by other youths, who then examined his genitals and called him Jud, Jud. (Sinkó 1977: 47). It is quite likely that such attacks, as well as a barrage of less violent ones of the sort now called micro-aggression in the literature on the experiences of 
Deák, George. "Ervin Sinkó's Search for Community: The Early Years, 1898-1919.” Hungarian Cultural Studies. e-Journal of the American Hungarian Educators Association, Volume 12 (2019) DOI: 10.5195/ahea.2019.348

African Americans (Sue 2008), were formative in Sinkó's personality and his political outlook, as they were for many Hungarian Jews.

The Spitzers were Neolog Jews and therefore belonged to a denomination of Judaism which had assimilated into Hungarian ways of language and dress (Sinkó 1990: 37, 44). Neolog Jews formed the majority of the Jewish community found in the area surrounding Szabadka, the city where the Spitzers moved when Ferenc reached gimnázium age. The Neolog character of the majority of Szabadka's Jewish community was reflected in the large, art nouveau synagogue (boasting a pipe organ, as in Christian churches) that the congregation (consisting of more than three thousand members) had built in 1902 (Klein: 216-226). Signaling his identification with Magyar rather than Jewish culture, the precocious writer, Ferenc Spitzer, unofficially adopted the pseudonym of Ervin Sinkó in 1914 when he began to publish as a columnist for the local newspaper, Bácsmegyei Lapok ['Bács County Paper'].

The modernizing tendencies of Sinkó's family can also be seen in an episode described by Sinkó in his Szabadka diaries. Although Dr. Bernát Singer, Sinkó's maternal great uncle was the Neolog chief rabbi of Szabadka, this circumstance did not signify a deep faith in God on the part of the family. His mother was once so distraught at the death of a relative in childbirth that she declared to her uncle, the rabbi, at the relative's funeral: "Hát Tisztelendö úr, hogy ez megtörténhetett, én mondok valamit... Nincs Isten!" ['Well, Rabbi, that such a thing could happen, let me tell you something ... there is no God!'] The rabbi replied with a pained expression on his face, “No és ha nincs?” ['So, and what if there isn't one?'] (Sinkó 1990:44). The implication is that to the rabbi, the social and ethical aspects of religion were at least as important as theological ones.

Despite their cultural integration, the family was socially isolated from their non-Jewish neighbors in Szabadka. This is reflected in an episode early in the first chapter of Optimists. The novel, whose plot we have summarized above, opens in the city and describes the appearance of the house of Dr. Seiden. Although he is an important member of the provincial middle class and, through his profession, of the entire town, Dr. Seiden's house remains shut off from the community with the exception of the city's weekly market day:

Móric Seiden returned home to his father's house, the eight-windowed, corner residence resembling a nobleman's country mansion which belonged to the outstanding specialist, the highly-respected gynecologist, Dr. Seiden, a doctor also renowned for his scientific articles published in the professional journals of Budapest, indeed, even in those of Vienna and Munich. With its large, double-winged gate of oak, its heavy, brass door-handle, and its windows darkened by closed shutters, the meticulously maintained, light-yellow building had something of the aloof, reclusive dignity of its owner. ... Except for the weekly market day the house seemed uninhabited and its walls frozen into silence (Sinkó 2010: 5, all translations by George Deák).

Seiden Móric hazaérkezett az apai házba, haza, Seiden doktornak, a pesti, sőt bécsi és müncheni szaklapokban közölt tudós cikkeiröl is nevezetes kitünö specialista, a tekintélyes nöorvos afféle vidéki kúriának is beillö nyolcablakos sarokházába. A gondosan karbantartott, világossárga épületben, a nagy, szárnyas tölgyfa kapujával, 
Deák, George. "Ervin Sinkó's Search for Community: The Early Years, 1898-1919.” Hungarian Cultural Studies. e-Journal of the American Hungarian Educators Association, Volume 12 (2019) DOI: 10.5195/ahea.2019.348

fényes, nehéz, sárgaréz kilincsével és a csukva tartott spalettáktól elsötétített ablakokkal, volt valami, akárcsak gazdájában, a házban is az elzárkózó visszavonultság méltóságából. Bár hetivásár idején távoli tanyákról és a környékröl érkezö, sorukra váró betegekkel, piros huzatos ágynemüvel egész kis szekértábor támadt a ház elött, a rendelóórákon kívül mintha csendbe dermedtek volna a lakatlan falak.

Semi-isolation was both imposed upon and chosen by the generation of Sinkós parents and older relatives. On the one hand, it was "imposed" by a resurgent anti-Semitism that became widespread after the Tiszaeszlár blood libel case of the early 1880s (Bihari: 251). Even though the charges surrounding this case were dismissed, anti-Semitism continued to increase as the Jewish community became more prosperous and as newer, oppositional political parties such as the short-lived Antiszemita Párt ['Anti-Semitic Party'] and the more successful Katolikus Néppárt ['Catholic People's Party'] began to use anti-Semitism to increase their appeal (Bihari: 22; Róna: 57). On the other hand, the isolation was "chosen" by the older, established members of the Jewish community as a means of defending the materially comfortable lifestyle they had created. Jews of this generation sought to defend their position by clinging firmly to the mainstream liberal-nationalist parties. Sinkó's rejection of the older generation's attempts to compromise with the "outside" world can be seen in his reaction, recorded in his diary, to the death in 1916 of his great-uncle Bernát Singer: "Poor, sweet, pure Dr. Singer! He belonged still to a transitional generation. But he was pure, even if ineffective" ['Szegény, édes, tiszta Singer dr.! Ö még az átmenetek embere volt. De tiszta volt, ha erötlen is volt'] (Sinkó 1990: 44).

The young and self-confident Sinkó chafed at his parents' attempts to fit into Hungarian society. He would go on to seek to overcome his own isolation from his neighbors and find a more "effective" communities within Hungarian society than what was available to his elders had by joining and helping to invent various movements to reform not just Hungary but the world. The first of these alternatives was Social Democracy. The Social Democratic movement had been making headway in the economically developing Dévidék region among agricultural, construction and industrial workers. In his early gimnázium years, before the war, Sinkó volunteered at the Munkásotthon ['House of Laborers'] to organize a library. In this Social Democratic institution, he experienced an encouraging and accepting social environment that he had not been able to find in Apatin nor, apparently, in his gimnázium in Szabadka from which he soon dropped out. "In the Munkásotthon no one cared about race, religious affiliation or nationality: Hungarian, Serbian, and German workers sat next to each other...." ['A munkás otthonban senki sem törödött fajjal, felekezettel, nemzetiséggel, magyar, szerb, német munkások ïltek együtt ....'] (Sinkó 1977, 50).

The wish to overcome anti-Semitism was probably the primary reason for Sinkó's attraction to Social Democracy, although it may not have been the only one. He cites an additional reason for this in Facing the Judge: the sympathy he felt for the exploited in his own bourgeois household in Apatin. He was uncomfortable with his family's treatment of their female servant as an outsider. She was not allowed to have dinner with the family; his mother did not trust her and hid the house keys lest the servant let in someone even more dangerous than herself. "Had I not suffered from the enmity that existed between myself and the street (that is, the Swabian boys), I might not have noticed the relationship that existed between the family and its servant" [ 'Ha nem szenvedtem volna az ellenséges idegenség alatt, mely az 
Deák, George. "Ervin Sinkó's Search for Community: The Early Years, 1898-1919.” Hungarian Cultural Studies. e-Journal of the American Hungarian Educators Association, Volume 12 (2019) DOI: 10.5195/ahea.2019.348

utca közt és köztem fennállott, talán ezt a család és cseléd közti viszonyt észre se vettem volna'] (Sinkó 1977, 50).

Sinkó became disillusioned with the Social Democrats at the beginning of the war when the party in Hungary rallied to the national flag, as did the socialist parties of most European states. Sinkó's intellectual energies turned from socialism to absorbing the rich literary and cultural life offered by his private tutors and the vibrant life around him. While he deplored the formal education of the gimnázium, he established a close relationship with the tutors his parents hired to prepare him for his maturation examinations. He also befriended an array of intellectuals who lived or traveled through Szabadka, which (despite Sinkó's portrayal of it in Optimists as a backwater) had the active intellectual life that could be expected of what was, at the time, the third largest city in Hungary. Sinkó was a voracious reader of Anatole France, Émile Zola, George Bernard Shaw, Baudelaire, Ibsen, Strindberg, Kierkegaard as well as the authors of the modern literary magazine, Nyugat ['The West'] including the modern poetry of Endre Ady (Bori 1977: 286). Ady, the greatest celebrity of early twentieth-century Hungarian counter-culture, had a great influence on Sinkó's first published volume of poetry, Éjszakák és hajnalok ['Midnights and Dawns'], which came out in Szabadka in 1916.

During this period of personal and intellectual growth in the middle years of the war, the author who made the greatest impression on Sinkó was Friedrich Nietzsche whose theories and heroes fed Sinkó's need for individual self-exploration and self-expression. Sinkó's attempt to establish an identity turned from the collective one promulgated by Social Democracy to the individualism of the Superman who is able to shake off the shackles of tradition (Sinkó 1916: 36).

Sinkó's attempts at forming a new identity are best reflected in his Szabadka diaries, written between March 1916 and April 1917. The budding writer recorded his most intimate thoughts and actions so that he could "sit in judgment before himself" ['itélöszéket tartatni önmagunk felett'] and perform a type of "vivisection" ['viviszekció'] (Sinkó 1990: 25). In these diaries we see a young Sinkó struggling with his self-image as an artist, a Jew, a prospective soldier and a sexual being. The reader of these diaries is at times surprised by an aggressiveness evident in two areas: first, his relationship with (some) Jews, and second, his sexual relationships with women. In the following section, I will examine how his aggressive feelings and behaviors are recorded in his diaries and also show how similar aggressive events are reflected in Optimists. Clearly, these were issues in his youth which the more mature novelist wished to present as important to his development.

To avoid misunderstanding, it must be recognized that although Sinkó refused to follow his elders in their particular accommodations to Judaism and Hungarianness, he retained an affection for the Jewish community from which he came. The concept of Jewish self-hatred that some writers (such as Robert Wistrich: 31-45) have used to explain the way in which many Jews (including the partly Jewish Karl Marx) turned to socialism, cannot be applied in Sinkó's case without the risk of committing serious distortion. Indeed, in his diaries Sinkó wrote lovingly and with pride of his Jewish ancestors, and of his great-uncle, the rabbi, even while rejecting the rabbi's political and religious world-views. Sinkó certainly bridled at all expressions of antiSemitism. At the same time, he expressed negative and aggressive feelings toward any Jew who embodied Jewish stereotypes, whether in appearance, manners, or economic behavior, or who criticized him for his distancing himself from the group. There is an episode in his Szabadka diary of March 1916 which can also be interpreted as an expression of this attitude. 
Deák, George. "Ervin Sinkó's Search for Community: The Early Years, 1898-1919.” Hungarian Cultural Studies. e-Journal of the American Hungarian Educators Association, Volume 12 (2019) DOI: 10.5195/ahea.2019.348

Yesterday I was angry with myself. There is a cheeky Jewish kid here is Szabadka-he graduated [from gimnázium] last year-who constantly annoys me with his impudence. Yesterday, as is his custom, as he was coming towards me on the street, already from afar he grinned and shouted out, 'Good day, Mr. Poet.' Losing my temper, I turned around. As I squeezed both of his arms a bit, I warned him that flies who shit on the heads of giants are themselves not giants but: shitty flies.... The kid will not leave off with his impudence. I fear that at some point I may get so angry that I will slap him on the face right in the street (Sinkó 1990: 29).

Tegnap haragudtam magamra. Itt van Szabadkán egy orcátlan zsidó kölyök - tavaly érettségizett - és szemtelenségeivel állandóan zavar. Szokás szerint tegnap is, hogy szembejött velem, vigyorogva kiált messziröl:

-- Jó napot, költö úr!

Én már kijöttem a sodromból, megfordultam, kissé megszorítva a két karját figyelmeztettem, hogy legyek, akik óriások fejére szarnak, még nem óriások, hanem csak - szaros legyek. ... A kölyök háborítlanul folytatja a szemtelenkedést. Aggódom, hogy egyszer földühödöm és nyílt uccán felképelem.

What is most remarkable about the above incidence is the violence of the reaction to what was, after all, just a teasing greeting from a fellow Jew. Perhaps he felt the lad's mockery to be a rebuke from the Jewish community which Sinkó seemed to be abandoning by dropping out of school and omitting all Jewish themes from his modernist poetry.

The negative feelings that Sinkó had toward his own Judaism is an important theme in the first chapter of Optimists. A key episode of physical aggression on the part of Báti takes place on the night of October 31,1918, the day marking the end of the war, the dissolution of the Austro-Hungarian Monarchy and the bourgeois democratic Chrysanthemum Revolution that placed Mihály Károlyi in power. The scene culminates in the suicide of Móric Seiden, the obviously Jewish, over-indulged only son of Dr. Seiden, the description of whose shuttered house I have quoted above. Móric wishes to be a member of the "artists' table," a circle to which Báti distantly belongs. The socially awkward, untalented and easily victimized Móric is even more peripheral at this table than Báti is. At the same time, Móric enjoys undeserved privileges. Unlike his father, who has earned his wealth, Móric spent his law school years fruitlessly and in dissipation. When the war came, his father arranged for Móric to be tucked away at a Swiss sanitarium. Upon his return to Szabadka, Móric throws a party for the members of the artists' table to celebrate the end of the war at his absent parent's opulent home. Everyone drinks excessively and makes a mess of the house with their cigarette butts and smashed wine glasses. Worried at one point about the disorder, Móric ducks under the table to pick up the butts and the shards when he thinks no one will notice. Seated at the table, Báti surreptitiously but quite deliberately steps on Móric's hand so that it is cut by the glass. Later that night, a series of events heaps humiliation after humiliation upon the unfortunate Móric, who eventually brandishes a gun in desperation. He threatens his tormentors but, when further taunted as a coward, turns the weapon on himself. After a cursory police investigation, everyone, including Báti, ambles home, alone, ashamed of their part in the suicide. 
Deák, George. "Ervin Sinkó's Search for Community: The Early Years, 1898-1919.” Hungarian Cultural Studies. e-Journal of the American Hungarian Educators Association, Volume 12 (2019) DOI: 10.5195/ahea.2019.348

Sinkó offers a hint at how to explain Báti's aggression in the following exclamation made by Báti to his friend and violin teacher soon after stepping on Móric's hand: "Nothing is worse than disgust ...the most miserable, dirty feeling is disgust" ['Utálkozni...ez a legnyomorultabb, legsárosabb érzés, az utálat'] (Sinkó 2010: 48).

Just before his act of violence, Báti caught a glimpse of his own dissipated image in the mirror and felt disgust, which he redirected against Móric, a type of decadent Jew who made Báti ashamed of his own Jewishness. While there are many layers to this violence (as there are to all acts of violence), the fact that it happens at the beginning of the novel - just before Báti goes to Budapest to join the revolution that he hopes will destroy the entire decadent bourgeois world provides a possible motivation for why Sinkó's character feels so strongly about displacing the social system he holds responsible for both the war and all oppression, including his own need to feel defensive about his Jewish origins. It is also significant that the scene ends with Báti feeling ashamed of his action, in spite of Sinkó's depiction of him as possessing a brash, aggressive nature. Yet it will only be during the Hungarian Soviet Republic and its wanton use of violence that Báti, like Sinkó, learns to overcome his aggressive impulses.

As an adolescent, Sinkó felt not only attraction but also aggressiveness towards females, whether Jewish or not. Let us now return to the direct evidence of Sinkó's diary. Not surprisingly, losing his virginity was a priority for Sinkó in 1916, on a par with his intellectual and artistic pursuits. A May 1916 diary entry states, "I intend to initiate myself into the secrets of Doctor Ecstasius as soon as time permits" ['A Doctor Ecstasius titkaiba amint idöm engedi, szándékom beavatni magam'] (Sinkó 1990: 39). As was quite common for members of his class, Sinkó's initial excursions into carnality were provided by prostitutes; most of these experiences left him feeling empty (46). He courted some women among his acquaintances whose husbands happened to be away at the front. One such woman was his landlady, Erzsike, in Palicsfürdö, a spa village near Szabadka where he would retreat for days to read and write (47). The mother of two small children, Erzsike was a cultivated, middle-class woman whose husband was serving in the army. Although she was obviously attracted to him, it can also be said that Sinkó pursued her relentlessly. At one point in their physical relationship Erzsike, fearing discovery and complications, did not wish to go further. Yet, one night, as he records in his diary, "I embraced her, dragged her to the couch, and kissed her lips until they bled." ['Magamhoz öleltem, a diványra vonszoltam, véresre csókoltam'] (49). She repeatedly tried to break off the relationship, but Sinkó persisted, often using physical force, almost, but not quite to the point of rape (49-50). Sinkó describes other similar, if somewhat less extreme incidents that took place with other married women from his social class $(52,53,57)$.

Sinkó's brutish behavior towards women at this time is most clearly demonstrated by an encounter with a peasant girl who greeted him while he was walking in the countryside around Palicsfürdö. Having encountered her in the afternoon, they arranged to meet later in the day. The girl dressed in her best traditional outfit for the rendezvous. They went for a walk that ended in a wrestling match in the grass, though again he did not go so far as to rape her. The young girl was shocked that men really did act as she had previously heard from her girlfriends. In his diary, the unrepentant Sinkó showed a fascination for the peasant girl's reaction, including her rustic but intelligent way of expressing her surprise at his rudeness. Thus, besides his sexual urgency, one can sense in Sinkó's description a curiosity about the peasantry, one of the several communities in Hungary from which he was isolated. 
Deák, George. "Ervin Sinkó's Search for Community: The Early Years, 1898-1919.” Hungarian Cultural Studies. e-Journal of the American Hungarian Educators Association, Volume 12 (2019) DOI: 10.5195/ahea.2019.348

A decade and a half later, Optimists presents in fiction an act of sexual aggression reminiscent of the incidents that we have just discussed. When Erzsi, a member of the group of radical Marxists that he met in a café, comes down with the deadly Spanish flu, it is Báti who stays by her bedside at her absent father's villa (who happens to be a Jewish war-profiteer whose way of life both he and Erzsi reject) and nurses her back to health. Meanwhile, Erzsi's married lover, the revolutionary poet Lénárt, neglects her. After Erzsi recovers, Báti confesses his love, but she reveals that her heart already belongs to Lénárt. Crushed, Báti is further tormented when he realizes later that night that Erzsi and Lénárt are making love in the room adjacent to his bedroom in the villa. Out of a sense of pity for the way she has treated Báti and to show gratitude for his help during her illness, Erzsi offers herself to Báti the next morning when they are alone in the villa. Báti lies in bed with her, listening to her sad life story but not consummating the relationship because Erzsi makes it clear that she cannot love him. That night, Báti visits her again and uses force to have his way with her (Sinkó 2010, 367). Although Erzsi tolerates the towering Báti's aggression without offering serious resistance, their relationship temporarily ends, to be resumed on a more promising note only towards the end of the novel. By that time Báti will have been ethically and politically transformed, having consciously rejected all use of violence, whether for personal or political ends.

\section{Becoming a Communist}

As is well known, what differentiated Social Democracy from communism as defined by Lenin was that communists accepted, indeed, advocated the use of violence and dictatorship for the purpose of attaining a quick transition to a classless, just society. By the end of the war Sinkó's frame of mind led him to join the Leninist movement that was sweeping across Russia and into Hungary. His war experience and the personal aggressiveness that he had experienced before being sent to the front impelled him in this direction. At the same time, war reactivated a sense of empathy in him which would germinate at a later point in our story. Violence and empathy mixed in Sinkó and vied with each other as he struggled to define himself at the end of his adolescence.

Sinkó was drafted in May 1916 and was deployed to the Russian front in November 1917 (39, 42, 402 fn 17). Even before he left Hungary, contact with wounded front-line soldiers changed Sinkó, reinforcing his empathy with his fellow human beings. In February 1917, he was sent to Budapest to a military hospital to seek treatment for an illness. What he observed there made a deep impression on him:

My illness brought me closer to people.... There were several sick soldiers in my room. When they complained of their pains, I experienced the same pains with incredible vividness. I was surprised at how interested I was in hearing their most inane and ordinary stories. I observed how they spoke, what it was that they considered most important to emphasize, and I was surprised, as if I were discovering a new world (Sinkó 1990: Diaries: 51).

Betegségem közelebb vitt az emberkhez. [...] Szobámban volt néhány beteg katona, akik ha fájdalmaikról panaszkodtak, megdöbbentö képzelettel szenvedtem fájdalmaikat. Csodáltam az érdeklödést, amellyel legostobább és legmindennapibb történeteiket 
Deák, George. "Ervin Sinkó's Search for Community: The Early Years, 1898-1919.” Hungarian Cultural Studies. e-Journal of the American Hungarian Educators Association, Volume 12 (2019) DOI: 10.5195/ahea.2019.348

hallgattam. Megfigyeltem, hogyan beszélnek, mi az, amit legfontosabbként kiemelnek, és csodálkoztam, mintha egy új világot fedeznék fel.

A major breakthrough in Sinkó's personal development occurred after his deployment to the Russian Front. The senselessness of the slaughter and the regimented life of military service increased his hatred of the ruling classes and the capitalist system. At the same time, the horrors that Sinkó experienced during his period of service did much to turn him against violence. Forced to watch an execution of Hungarian deserters, Sinkó was forever haunted by the expression of fear he saw in the eyes of the men as they faced the firing squad (Sinkó 1977: 62). The net effect of his contradictory feelings of anger and empathy at the end of the war was to turn Sinkó into a Leninist revolutionary. He learned about Leninism when Red Army soldiers crossed the front lines to fraternize with Sinkó's unit during the ceasefires held around the time of the March 1918 negotiations of the Brest-Litovsk Treaty between Russia and the Central Powers (Sinkó 1977: 64). Such fraternization on the Eastern Front in the spring of 1918 indeed occurred widely (Wheeler-Bennett: 145).

Sinkó was in Budapest at the end of October 1918 as the Austro-Hungarian Monarchy was disintegrating and the moderate revolution associated with Count Mihály Károlyi, supported by a number of bourgeois liberal parties and the main body of the Social Democrats, overthrew the old regime. Sinkó had returned from Galicia some months before and was fortunate not to be sent to the Italian Front. In Budapest, he became involved with the now revolutionary group to which Komját, Révai, and Irma Rothbart belonged. Sinkó's Budapest friends — writers, students, and activists - supported the radical wing of the Social Democratic Party led by Otto Korvin and advocated a total break with capitalism, a policy that the Károlyi regime was not prepared to follow. The regime was in general pro-capitalist and eager to win the support of the victorious Western powers. In November 1919 Sinkó worked with Hevesi, Komját and Révai to found a journal called Internationale whose purpose was to agitate for Hungary's participation in what they saw as the unfolding world revolution spearheaded by Leninist Russia (Sinkó 1990: 70, 404 fn 13). The initial capital for Internationale was supplied by Irma Rothbart, who had legally come into her dowry by entering into a pro forma marriage with Hevesi, about whom her father knew only that he was a well-educated engineer. With the marriage contracted expressly to fund the journal, Irma Rothbart and her fellow revolutionaries felt no compunction about misleading her father, whom Sinkó portrays negatively as a Jewish war profiteer in Optimists (Sinkó 2010: 154). Internationale was soon taken over by the Party of Communists in Hungary (KMP), founded at the end of November 1918 by Béla Kun and his entourage of former prisoners of war, just returned from Russia with funds and instructions from Lenin. Sinkó and his friends were early members of the party. The members of the Internationale group were almost all of Jewish background. No doubt they were attracted to the universalist creed of the Communists for similar reasons as Sinkó: a sense of rejection from Hungarian society for their religious background whose rituals and beliefs they had long left behind.

\section{Becoming a Non-Denominational Christian}

Sinkó's attraction to Christianity, which he saw primarily as a commitment to nonviolence and love for one's fellow man, began just weeks before the communists gained power as the dominant force within the Hungarian Soviet Republic which was declared on March 21, 
Deák, George. "Ervin Sinkó's Search for Community: The Early Years, 1898-1919.” Hungarian Cultural Studies. e-Journal of the American Hungarian Educators Association, Volume 12 (2019) DOI: 10.5195/ahea.2019.348

1919. Gradually, in the course of the one hundred-thirty-three days of the regime, Christianity, as Sinkó interpreted it, came to

displace his attachment to communism. In February 1919 the communists staged demonstrations in front of the headquarters of the Social Democratic daily, Népszava ['People's Voice'], in an attempt to bring down the Károlyi government and thereby instigate a Leninist revolution. The government decided to suppress its opponents on both the right and the left and ordered the arrest of communist agitators, including Sinkó. The communists had directed Sinkó to take refuge in the nearly empty Buda villa of an absentee count. The villa had been placed under the care of a wounded war veteran who had since become a communist and who was full of vengeance against those he held responsible for his debilitating injuries. The only other occupant of the residence was an elderly footman, a pious Lutheran whose interpretation of the Bible caught Sinkó's attention. Their chance encounter blossomed into admiration on both sides. Sinkó became alarmed when he learned of the fanatical veteran's intention to kill the footman lest he report the communists to the authorities. Sinkó tried to convert the footman to the egalitarian creed of the communists. He succeeded in doing so, but the footman also influenced Sinkó, who saw in the message of universal love and spiritual peace that the old man conveyed through his many quotes from scripture an attractive alternative to the véresszáju ['bloodthirsty'] slogans that Sinkó and his associates were scribbling on the walls of Budapest's buildings by night (Sinkó 1990: 76-77, 81).

Throughout the development of Sinkó's political ideas, and in counterpoint to the unnamed footman's Christian message, Sinkó's personal encounters with the philosopher György Lukács (1885-1971) played an important role. The exact time of Sinkó's first meeting with Lukács and his ideas is not clear. Already at the end of 1918, Sinkó may have attended some sessions of the Sunday Circle, a discussion group of leftist (although not necessarily Marxist) intellectuals that took place at the home of the writer Béla Balázs (Sinkó 1990: $411 \mathrm{fn} 38$ ). Lukács was the center of this "circle" which gathered such luminaries as the sociologist Karl Mannheim, the novelist Anna Lesznai, the journalist György Káldor, the art historian Arnold Hauser, and the polymath Mihály Polányi. During his prewar doctoral studies in Berlin and Heidelberg, Lukács had worked with Max Weber and Georg Simmel and become deeply steeped in the then current idealist (as opposed to materialist or empiricist) ethical trends in German philosophy which owed much to Immanuel Kant and Søren Kierkegaard. After the October Russian Revolution, Lukács attempted to find an ethical justification for the violence and dictatorship required to secure the "victory of the proletariat." Sinkó was fascinated by Lukács's literary and philosophical erudition and certainly sought him out personally by the beginning of the Hungarian Soviet Republic. In his 1920 memoir, Sinkó refers to Lukács as mesterem ['my master'].

Lukács's thoughts on the ethical justifiability of revolutionary violence were evolving quickly as he observed world and local events. In December 1918, in "Bolshevism as an Ethical Problem," Lukács wrote: "The dilemma of the Bolsheviks may be stated thus: Is it possible to achieve the good by means that are evil, to achieve freedom via oppression?" [Az $O$ [bolsevikek] dilemmájuk így hangzik: lehet-e a jót rossz eszközökkel, a szabadságot az elnyomatás útján elérni?'] (Lukács 1918: paragraph 7). In this essay Lukács still answered the question in the negative; by March 1919, when the communists came to power, Lukács had accepted Leninism and declared that communists would have to sacrifice their souls and accept the sin of murder in 
Deák, George. "Ervin Sinkó's Search for Community: The Early Years, 1898-1919.” Hungarian Cultural Studies. e-Journal of the American Hungarian Educators Association, Volume 12 (2019) DOI: 10.5195/ahea.2019.348

order to redeem the world. Echoing the German writer Friedrich Hebbel (1813-1863), Lukács used the metaphor of the biblical Judith who, as she is about to cut off the head of Holofernes, the enemy of the Jews, asks, "if God has placed sin between me and the deed required, who am I that I should be able to evade it" (Congdon: 141 Congdon's translation; Sinkó 2010: 248). The use of such terminology as "soul" and "sin," commonly found in the discourse of both Lukács and Sinkó, could hardly be considered orthodox Marxism and certainly not Leninism, even if Lukács and Sinkó used the terms metaphorically.

As the followers of Béla Kun came to power, Sinkó accepted Lukács's argument for revolutionary violence, but came to reverse himself in the course of his own exercise of official power during the Hungarian Soviet Republic. In The Way as well as in his later novelistic treatment of the events in Optimists, Sinkó explained his gradual rejection of violence, including both its philosophical underpinnings and its actual use, and advocated its replacement by a Christian-inspired ethical pacifism. This break unfolded in a number of steps: when the Soviet Republic was formed, Lukács become the commissar of education and charged the still eager Sinkó with establishing a section that would educate workers in the proper világszemlélet ['world view'] (Sinkó 1990: 90). In this role, Sinkó wrote a plan which reflected Lukács's position concerning the ethical justification for revolutionary violence, but Sinkó also insisted on teaching an ethics of brotherly love for all. Sinkó mixed Marxist and Christian terminology in the official plan: he wanted to instill krisztusi koncepciójú testvériség ['Christ's concept of fraternity'] (91, 411-412 fn. 40) so that an educated working class would limit the use of violence by the organs of power once the power of the bourgeoisie had been broken.

The deteriorating military situation in the Hungarian Soviet Republic interrupted Sinkó's educational mission. He was dispatched to the provinces to recruit soldiers for the Hungarian Red Army so that it could repel the Romanian, Czechoslovak and Yugoslav occupations that were being supported by western Entente powers. Away from the intellectual discussions with Lukács, he was soon disappointed in the unethical way that the revolution was unfolding; travelling with a peasant lad who had been assigned to help him in his recruiting efforts, Sinkó was disillusioned by the young man's opportunism and his uninhibited mendacity when talking to the prospective recruits (Sinkó 2010: 593; Sinkó 1990: 84-86). He also recognized that the peasantry was not moved by his own principled exhortations.

In May, Sinkó became city commandant of Kecskemét, an important city southeast of Budapest (Sinkó 1990: 95). The basic facts of Sinkó's activities there, as described in The Way and in Optimists are corroborated by the novelist József Lengyel's account contained in his memoir, Visegrádi út ['Visegrad Road'] (even though this work is full of criticism for Sinkó), and by the research of Romsics (Romsics 1982) and Bosnyák (Sinkó 1990: 399 ff). In Kecskemét, Sinkó was horrified by the arbitrary and terroristic methods which the earlier city commandant and his police had used to fill the city's jails and coffers. The counterrevolution gained many supporters in Kecskemét due to the regime's violence and its unpopular policies of collectivization. Sinkó called in the political police from Budapest, the self-styled Lenin fiúk ['Lenin Boys'] to shore up the unreliable local authorities. But the political police, wishing to instill fear into the population, shot András Vén, a former policeman of the old regime, without provocation. Looking through the personal effects of the dead man-especially the picture of the "handsome, calm, ordinary" Vén and his wife sitting self-consciously for a photographer, with a baby on Vén's knee- deeply affected Sinkó. When he asked why the man had been shot without due process, the "Lenin Boys" explained that they were afraid of the reaction back in Budapest: 
Deák, George. "Ervin Sinkó's Search for Community: The Early Years, 1898-1919.” Hungarian Cultural Studies. e-Journal of the American Hungarian Educators Association, Volume 12 (2019) DOI: 10.5195/ahea.2019.348

"If we had gone back dry, what would the boys have said!" ['Ha szárazon mentünk volna vissza, mit mondtak volna a fiúk!'] (Sinkó 1990: 102).

Sinkó advocated the use of leniency and gentle persuasion to win the population over to the side of the communists. About one hundred peasants from the nearby puszta ['plains'] of Szentkirály, who had been bribed and cajoled to rebel against Soviet rule by counterrevolutionary former landlords and officials, were put on trial. Sinkó convinced the judges to mete out short sentences for most offenders, pardon many and forego all capital punishment. Sinkó justified his refusal to use revolutionary terror in Christian terms. He explains in his memoirs that he was influenced by a conversation in Kecskemét with an elderly peasant, a Nazarene, who came to see him. The Nazarene's were one of several Christian sects that had spread through central Hungary in the late nineteenth century. Their main tenet was nonviolence, specifically the commandment "Thou shalt not kill" (Paládi-Kovács 1990: http://mek.oszk.hu/02100/02152/html/07/339.html). The elderly man pleaded for leniency for the peasants. "You must teach not how to fight but how to love and how to forgive. And that is how you should live" ['És nem harcra, hanem szeretetre és megbocsátásra kell tanitani. És úgy kell élni'] (Sinkó 1990: 103-105). It is noteworthy that Sinkó's arrangement for leniency by the judges was supported by some of his superiors in Budapest who, as Romsics points out, might have feared that executions would incite further unrest in an already volatile region (431 fn. 82). But Sinkó's policy also had its opponents in the Central Governing Council, four members of which (including the young Mátyás Rákosi, who later became a Stalinist dictator of Hungary) visited Kecskemét to investigate. On June 20th, Sinkó was relieved of his post and sent back to the capital (110, $434 \mathrm{fn} .94 ; 445 \mathrm{fn}$. 125). He was, however, allowed to retain his seat on the Központi Munkástanács ['Central Committee of Workers'] (121).

At the end of his Kecskemét travails, Sinkó realized that he could no longer hold the communist world view. He would write a year later: "One thing is certain, I say: I was no longer a communist... I found the law within myself. The law is love" ['Egy biztos, mondom, kommunista már nem voltam ... A törvényt megtaláltam magamban, a törvény a szeretet'] (116). As for an alternate world view akin to Christianity, he writes, "My faith was not yet strong, but I knew what I had to do" ['A hitem nem volt erös, de már tudtam mit kell tenni'] (116). That is, he had to follow the example of the ember-Krisztus ['the human-Christ'] and other prophets such as Buddha, Socrates and the Stoic philosopher, Epictetus (116). Sinkó realized that by preaching a creed akin to Christianity, he might be lending his support to the "anti-Christ, the counterrevolution," and therefore kept his thoughts mostly to himself.

Key scenes in Optimists also reflect Sinkó's concern with the dilemma of the choice between support of the revolution and a commitment to non-violence. In late June 1919, as the regime entered its death throes, Báti returns to Budapest from Kecskemét and seeks out Erzsi. She has remained an active and consistent revolutionary, an official in the Commissariat of Public Education who refused to use her position to release her own father from jail because it would have placed person about principle (Sinkó 2010: 625). When Báti finds her, she is about to board a train for Germany where she is scheduled to speak at the funeral of the murdered revolutionary leader, Rosa Luxembourg. On the platform, Báti confesses to Erzsi: 
Deák, George. "Ervin Sinkó's Search for Community: The Early Years, 1898-1919.” Hungarian Cultural Studies. e-Journal of the American Hungarian Educators Association, Volume 12 (2019) DOI: 10.5195/ahea.2019.348

I am no longer a communist... I want to tell you: one must not kill, never, for whatever reason, under any circumstances is it permissible to kill.

Erzsi remained silent.

Why don't you say something? asked Báti.

If only we had a choice! answered Erzsi. But you are able to choose, she continued, and though I was surprised by your statement, I know I need not fear for you (Sinkó 2010: 696).

-- [...] Erzsi, én már nem vagyok kommunista. [...] Meg akarom mondani neked: nem szabad ölni. Soha, semmiért, semmi körülmények között se szabad.

Erzsi még mindig hallgatott.

-- Miért nem szólsz semmit?

-- Ha választhatnánk! - válaszolta Erzsi - De te választhatsz. És azért, meglepett ugyan, amit mondtál, de nyugodt vagyok felöled.

Erzsi, who sees deeply into Báti's fundamental character, recognizes that he has made his choice about the kind of person he wishes to be.

Sinkó's own choice for pacifism was put to the test a few days after his return to Budapest. I will follow Sinkó's account in his memoir to demonstrate how he hesitated in his pacifism but ultimately became an advocate for a policy of leniency toward the regime's violent enemies. On June 24th, opponents of the revolution attempted a military attack on the government in Budapest. Although he realized that his actions contradicted his recent decision for Christian non-violence, Sinkó grabbed a gun and participated in the defense of the Party headquarters (Sinkó 1990: 123). Among the attackers were the students of the Ludovika Military Academy whose battle against the Budapest telephone exchange led to several deaths among the regime's defenders. The attempted coup was put down. The leaders were executed, including the officer who had commanded the students. Sinkó pleaded with Ottó Korvin, head of the political police, to spare the approximately one hundred young students from jail or worse and requested that their sentences be commuted to reeducation in a course that Sinkó would deliver. The goal was to turn them into moral, thinking people "through forgiveness, enlightenment, and love" (131). Sinkó was given permission for his program. As Tibor Hajdu has pointed out, the desperate situation of the Soviet Republic and the intervention of Aurél Stromfeld, head of the Red Army and a former Ludovika graduate himself, also played a part in granting this leniency (447, fn. 140). Sinkó devised and taught a course that included readings from Marxist literature as well as from Dostoyevsky, Tolstoy, and the Bible. Following the fall of the Soviet Republic on August 1, under the rule of Admiral Horthy's White Terror, the students returned the favor to Sinkó. Tasked with helping in the search and arrest of former communists, they turned a blind eye when they spotted Sinkó on the street as he fled from one hiding place to the next (Sinkó 1990: 144-46). 
Deák, George. "Ervin Sinkó's Search for Community: The Early Years, 1898-1919.” Hungarian Cultural Studies. e-Journal of the American Hungarian Educators Association, Volume 12 (2019) DOI: 10.5195/ahea.2019.348

I have outlined the tortuous path that led Sinkó through a series of phases that sometimes overlapped, from pre-war Social Democracy, through wartime Neitzscheism and communism and finally to an idiosyncratic interpretation of Christianity. Along with his ideological views, Sinkó's personality changed from one prone to a moderate amount of aggression (especially sexual) to that of a "gentle soul." What are the larger lessons that we can draw from this dramatic tale of changes in personality, politics, and ideology? I will start from the question of personality and continue toward the more general issues.

When viewing the long-term pattern of Sinkó's personality, it seems that his aggressiveness was not fundamental to his nature but was rather part of a temporary stage of adolescence, akin to developmental stages described by the psychologist Eric Ericson (Ericson: 261-266). Sinkó's sexual urges, his unresolved connection with the Jewish community and, in general, his need for community (which was frustrated by the anti-Semitism of the society around him) turned Sinkó toward a Nietzschean world outlook which he interpreted as giving him permission to exercise aggressions that were in fact contrary to his underlying temperament and the examples set by his family. The violence that he witnessed during the last years of the war made him prone to violent solutions for solving the problems of society as well, yet simultaneously increased his empathy for the sufferings of individual human beings. The violence of the revolution and the experience of the love for Irma Rothbart (even if still unrequited at the time of his transformation) further tempered Sinkó's emotions. His personality returned to the gentleness and decency that he had absorbed in the emotionally close-knit family of his early youth, a gentleness that he valued and praised already in his early adolescent days in his evaluation of Rabbi Singer.

We have seen how Sinkó's turning to communism was in part a reaction to the antiSemitism that he encountered as a child. Despite the large number of Jews in the leadership of the Soviet Republic and their common experiences regarding anti-Semitism, most Jews in Hungary did not become communists. This has been pointed out by János Gyurgyák in his important study of anti-Semitism (Gyurgyák: 104, 112). It is also illustrated by the following entry from Sinkó's 1920 diary. Sinkó, who had fled Hungary at the end of 1919, returned incognito to Szabadka (then part of the Kingdom of Serbian, Croatians, and Slovenes). Sinkó, apprenticing for a short time as a cabinet maker, happened to pass by the major Jewish synagogue of Szabadka on one of his errands. As the congregants were coming out, he had a panic attack. He wondered what had caused this feeling. Was it, he asked himself, the fear of being beaten up by members of the Jewish congregation for participating in the Soviet Republic (Sinkó 11990: 154)?

One of the factors that motivated Sinkó's rejection of communism was his objection to violence. This sentiment may have been more common among the participants of the Hungarian Soviet Republic than has previously been recognized. Without likeminded people who also saw violence as loathsome and harmful to the cause, Sinkó could not have convinced the judges in Kecskemét or Korvin in Budapest to treat large numbers of enemies of the Soviet Republic with leniency. Why some communist actors were revolted by violence while others favored its intensification can probably be best explained by differences in individual personalities, beyond the simple categories of class or ethnicity.

Conversion to Christianity, like joining the Communist Party, was chosen by a small minority of Hungarian Jews. Miklós Konrád points out that in Budapest between 1918-1920, when the long-term very low rate of Jewish conversions spiked temporarily, less than four 
Deák, George. "Ervin Sinkó's Search for Community: The Early Years, 1898-1919.” Hungarian Cultural Studies. e-Journal of the American Hungarian Educators Association, Volume 12 (2019) DOI: 10.5195/ahea.2019.348

percent of Jewish-born residents were converts to Christianity (Konrád: 587). Konrád clearly demonstrates that most Jews in the period that he studied (pre-World War I) converted to escape the disadvantages created by their Jewish status (588). Sinkó's motives for conversion, the trajectory that led to it and its form of a non-denominational Christianity were highly unusual. Technically, it cannot even be called a conversion. Like his slightly earlier turn to communism, Sinkó's turn to Christianity can best be seen as an attempt to create a new universal community in which differences of origin no longer mattered and in which humane ethical principles would rule. Not surprisingly, he found few followers.

In retrospect, one cannot but wonder at the naivety with which Sinkó, like the early communists in general, saw the future of the post-war world and within that, of Hungary. It is baffling how Sinkó, whose father was a merchant, or Lukács, whose father was a wealthy banker, had so little appreciation for the importance of economic markets. Ignác Romsics correctly characterizes the revolutionary circle to which Sinkó belonged as "young intellectuals without life experience and prone to romanticism" ['élettapasztalat nélküli és romantikára hajlamos fiatal ... értelmiség'] (Romsics 2003: 122). While recognizing Sinkó's naivety, we should remember that naivety was not limited to communists in the early twentieth century. It also characterized those, like István Tisza and the Emperor Franz Joseph, who thought in the late summer of 1914 that war would be over by Christmas, or those who expected, as the war was ending in 1918, that Hungarian territorial integrity would be largely preserved by the victorious powers. In contrast to the conservatives, what drove the naive hopes of people like Sinkó were their reactions to the inhumane situations - some of which were inconceivably so - that characterized the era: ethnic prejudice, great inequalities of wealth and status, and a willingness on the part of leaders to send millions to their meaningless and unnecessary deaths.

As a postscript, let us summarize the rest of Sinkó's life in the difficult times between 1919 and his death in 1967. Sinkó returned to the political left in the late 1920s as fascism began to spread throughout Europe. He wrote Optimists in the early 1930s and spent two years in the Soviet Union hoping to publish the novel. The couple were fortunate to be merely expelled from there in April 1937. Having survived Italian concentration camps as Jews in wartime Croatia the Sinkós, after years of penury, found a comfortable home in Zagreb after 1945. By 1955, Sinkó was finally able to publish Optimists as well as The Novel of a Novel, a condemnation of Stalinism and an argument in favor of the reform communism advocated at the time by the Yugoslav politician Milovan Djilas. Despite his criticism of dictatorship in both of the above works, Sinkó became a well-established member of Tito's regime. He led the Department of Hungarian Language and Literature at the University of Novi Sad from its founding in 1959 until his death and was a member of the Academy of Arts and Sciences after 1960. In 1968, the year following Sinkó death, the slogan of "Socialism with a Human Face" was raised in Prague. Sinkó can be seen as a forerunner of that well-intentioned but apparently overly-optimistic movement. 
Deák, George. "Ervin Sinkó's Search for Community: The Early Years, 1898-1919.” Hungarian Cultural Studies.

e-Journal of the American Hungarian Educators Association, Volume 12 (2019) DOI: 10.5195/ahea.2019.348

\section{Works Cited}

Bihari, Péter. 2008. Lövészárkok a hátországban: Középosztály, zsidókérdés, antiszemitizmus az elsö világháború Magyarországán ['Trenches on the Home-Front: The Middle Class, the Jewish Question, and Anti-Semitism in World War I Hungary']. Budapest: Napvilág.

Bosnyák, István. 1977. Ember a forradalomban, ember a soron kívuil. Vázlatok egy portréhoz, II ['A Man in the Revolution, a Man Apart: Sketches Towards a Portrait, II']. Ujvidék: Fórum.

Congdon, Lee. 1983. The Young Lukács. Chapel Hill: North Carolina.

Ericson, Eric H. 1963. Childhood and Society. New York: Norton.

Gyurgyák János. 2001. A Zsidókérdés Magyarországon: Politikai eszmetörténet ['The Jewish Question in Hungary. A Political History of Ideas']. Budapest: Osiris.

Klein, Rudolf, 2015. "A Mézeskalácsok mögött, a szabadkai szecesszió zsidó háttere” ['Behind the Gingerbread Houses: The Jewish Background of Szabadka's Secessionist Architecture']. Ed. Zoltán Dévavári et al. 2015. Élettôl életig a holokauszton át ['From Life to Life By Way of the Holocaust']. Újvidék and Szabadka: Fórum Könyvkiadó and Szabadkai Zsidó Hitközség.

Konrád, Miklos. 2014. Zsidóságon innen és túl. Zsidók vallásváltása Magyorországon a reformkortól az elsö világháborúig ['Judaism from Within and Beyond. Jewish Conversion in Hungary from the Age of Reform to the First World War']. Budapest: MTA BTK Történettudományi Intézet.

Lengyel, József. 1968. Visegrádi utca ['Visegrad Street']. Budapest: Kossuth.

Lukács, György. 1918. "A Bolsevizmus mint erkölcsi probléma” ['Bolshevism as An Ethical Problem']. Szabadgondolat ['Free Thought'] (Budapest), December, 1918, 228-32. Also in https://www.marxists.org/magyar/archive/lukacs/bmep.htm (Accessed 3/6/18)

Paládi-Kovács Attila, ed. 1990. Magyar néprajz nyolc kötetben, 7/3, Folklór: Népszokások, néphit, népi vallásosság. ['Hungarian Ethnography in Eight Volumes. 7/3. Folklore: Folk Customs, Folk Beliefs, Popular Religiosity']. Budapest: Akadémiai Kiadó.

Romsics, Ignác. 1982. A Duna-Tisza köze hatalmi-politikai viszonyai 1918-1919-ben ['The Situation of Political Power in the Region Between the Danube and the Tisza in 19181919']. Budapest: Akadémiai Kiadó.

Romsics, Ignác. 2003. Magyarország története a XX. században ['The History of Hungary in the Twentieth Century']. Budapest: Osiris Kiadó.

Róna, Tamás, Monika Mezei, eds. 2018. A Magyarországi zsidóság története ['The History of Hungarian Jewry']. Budapest: Szent István Társulat.

Sinkó Ervin. 1916. "Dr. Bibó István Nietzsche tanulmánya" ['Dr. István Bibó's Study of Nietzsche']. A Tett ['The Action'], July 1. http://digiphil.hu/o:atett-15.tei.142 (accessed 2/4/2019).

1977. Szemben a biróval ['Facing the Judge’]. Ed. István Bosnyák and Mihály Sükösd. Budapest: Gondolat. . 1990. Az Út. Naplók 1916-1939 [‘The Way: Diaries 1916-1939’]. Ed. Farkas József and László Illés. Budapest: Akadémiai Kiadó. This book contains, among other Sinkó writings, Szabadkai Napló 1916 ['Szabadka Diaries 1916'], Szabadkai Napló 1917 ['Szabadka Diaries 1917'], the autobiographical essay, Az Ut ['The Way'].

-------- 2000. Bezúzott háborús napló ['Pulped Wartime Diary']. Ed. István Bosnyák. Novi Sad: Jugoszláviai Magyar Mủvelődési Társaság. 
Deák, George. "Ervin Sinkó's Search for Community: The Early Years, 1898-1919.” Hungarian Cultural Studies. e-Journal of the American Hungarian Educators Association, Volume 12 (2019) DOI: 10.5195/ahea.2019.348

---------. 2010. Optimists. Történelmi regény 1918-1919-böl ['Optimists, Historical Novel from 1918-1919']. Budapest: Noran Libro.

---------. 2011. Egy regény regénye. Moszkvai naplójegyzetek 1935-1937 ['The Novel of a Novel']. Budapest: Noran Libro.

Sue, Derald Wing, Christina M. Capodilupo, and Aisha M. B. Holder. 2009. "Racial Microaggressions in the Life Experience of Black Americans." Professional Psychology Research and Practice, 39, 3, 2008, 329-336; corrected in 2009 in http://prfc-gr.org/wpcontent/uploads/Microaggressions-Black-Americans-PDF-Research_Generalresource_18.pdf (accessed 3/7/2018).

Wheeler-Bennett, John. 1938. "The Meaning of Brest-Litovsk Today." Foreign Affairs (pre1986), 17.000001, 137.

Wistrich, Robert. 1977. Revolutionary Jews from Marx to Trotsky. London: Harrap. 